\title{
POTENTIAL USE OF RAPD MARKERS IN CHARACTERISTICS OF CUCUMBER (CUCUMIS SATIVUS L.) HAPLOIDS AND DOUBLE-HAPLOIDS
}

\author{
MIECZYSŁAW ŚMIECH ${ }^{1}$, JOANNA SZTANGRET-WiśNIEWSKA ${ }^{2}$, \\ TERESA GAŁECKA ${ }^{1}$, AleKsandra KORZENIEWSKA ${ }^{1}$, LESZEK MARZEC ${ }^{1}$, \\ GRAŻYNA KOŁAKOWSKA ${ }^{1}$, URSZULA PISKUREWICZ ${ }^{1}$, KATARZYNA NIEMIROWICZ-SZCZYTT ${ }^{1}$ \\ ${ }^{1}$ Department of Plant Genetics, Breeding, and Biotechnology \\ Warsaw University of Life Sciences \\ Nowoursynowska 159, 02-776 Warszawa, Poland \\ e-mail: katarzyna_niemirowicz@sggw.pl \\ 2 Plant Breeding and Acclimatization Institute \\ Mlochow Research Center, Platanowa 19, 05-831 Mlochov, Poland
}

(Received: August 28, 2006. Accepted: December 28, 2007)

\begin{abstract}
A study was designed to obtain hapolid and double haploid (DH) plants from cucumber cultivars tolerant to Pseudoperonospora cubensis. The main goal was to identify RAPD molecular markers associated with downy mildew resistance. On average, $20 \%$ of embryos generated in two experiments, were converted to haploid plants. RAPD markers that differentiated susceptible and resistant $\mathrm{H}$ and DH plants were identified. Somaclonal variation in DH lines was seldom detected.
\end{abstract}

KEY WORDS: haploid embryo rescue, RAPD markers.

\section{INTRODUCTION}

Two methods of cucumber haploid production are known. The first method utilizes an in vitro culture of either ovules or ovaries. The second method, called haploid parthenogenesis, consists of pollination with irradiated pollen followed by haploid embryo rescue and in vitro culture (Gemes-Juhasz et al. 2002; Truong-Andre 1988; Niemirowicz-Szczytt and Dumas de Vaulx 1989; Sauton 1989; Przyborowski and Niemirowicz-Szczytt 1994; Caglar and Abak 1996).

In 1990 the Dutch seed company Nunehems Zaden BV (Haelen, The Netherlands) patented a method for ovule culture method (patent NP-374755), however, no data was provided on the efficacy and application of this invention. More recently, a similar approach was reported by GemesJuhasz et al. (2002). No information was reported on morphology and number of DH plants obtained in that study.

The second approach, the embryo rescue method, has given in general better results than the ovary culture (TruongAndre 1988; Niemirowicz-Szczytt and Dumas de Vaulx 1989; Sauton 1989; Przyborowski and NiemirowiczSzczytt 1994; Caglar and Abak 1996). In this method, pollination with an irradiated pollen resulted in direct formation of haploid embryos that developed into haploid plants. For instance, Przyborowski and Niemirowicz-Szczytt (1994) reported that an average of 1.2 to 3.1 embryos per fruit were obtained in six cucumber genotypes and approximately $50 \%$ of the excised haploid embryos developed into plants. Therefore this method was used to obtain haploids for molecular research presented in this work.

In Europe, severe outbreaks of downy mildew [Pseudoperonospora cubensis (Berk. et Curt.) Rostovzev] causing yield reductions on field-grown cucumbers have been reported during the past twenty years (Doruchowski and Łąkowska-Ryk 1992). An efficacious utilisation of genes for resistance in cucumber breeding would greatly accelerate the rate of release of resistant cultivars. Random Amplified Polymorphic DNA (RAPD) marker analysis technique is relatively inexpensive and is straight forward technologically. Therefore, this technique was chosen for the identification of putative marker-target gene associations. A second objective of our research was to identify RAPD markers that could be employed at early stages of plant development for the selection of resistant individuals.

A third objective was to determine the occurrence of somaclonal variation in the $\mathrm{DH}$ plants. The $\mathrm{DH}$ plants by the virtue of being produced in an in vitro system may be sub- 
ject to culture-induced somaclonal variation, and thus show genetic segregation in later generations. It is important to know whether somaclonal variation is a real and serious side-effect in DH production.

\section{MATERIALS AND METHODS}

\section{Haploid plant production}

The haploid embryo production utilised the process of haploid parthenogenesis (Przyborowski and NiemirowiczSzczytt 1994). Female flowers of three resistant to Pseudoperonospora cubensis hybrids' Krak', 'Frykas' and 'Izyd', and one susceptible hybrid 'Polan', were pollinated with pollen irradiated at $0.3 \mathrm{kGy}$ gamma rays, cobalt source, $0.80 \mathrm{~Gy} / \mathrm{min}$ at the Department of Food Safety and Public Health, Warsaw University of Life Sciences. Flowers of 40 plants of each cultivar grown at a Warsaw University of Life Sciences greenhouse at the Wolica Experimental Station were used in the pollination. Three to five weeks after pollination presence of individual haploid embryos was detected using a stereo microscope. The embryos were removed aseptically from the ovaries and transferred to E20A medium (Sauton and Dumas de Vaulx 1987). Embryos that developed into plants were maintained on MS medium (Murashige and Skoog 1962). The experiment was conducted during the months of May and June and then August and September.

Two methods of dipliodization were used. One method consisted of direct regeneration of plants from young haploid leaf tissue (Faris et al. 2000) and the second method was a colchicine treatment of apical meristems of $\mathrm{H}$ plants (Nikolova and Niemirowicz-Szczytt 1996). Direct regeneration from leaf explants of haploid plants obtained in the spring (May and June) was conducted in the autumn (September-November) of the same year, whereas the haploids obtained in the summer/autumn (August-September) were used in regeneration during winter/spring of next year (January-April).

\section{RAPD analysis}

The DNA was isolated from plants grown under greenhouse conditions $\left(23 / 25^{\circ} \mathrm{C}, 16 \mathrm{~h}\right.$ photoperiod, $1000 \mu \mathrm{mol}$ $\mathrm{m}^{-2} \mathrm{~s}^{-1}$ ) using the third and the fourth leaf from the apical meristem.. Four grams of leaf tissue were frozen in liquid nitrogen, followed by DNA extraction procedure according to Van der Beek et al. (1992).

PCR reactions were conducted using Gene Amp PCR System 9700 (PE Applied Biosystems, Forster City, CA, USA). Each $25 \mu \mathrm{L}$ of the reaction mixture contained $40 \mathrm{ng}$ template DNA, $0.2 \mu \mathrm{M}$ primer, $10 \mathrm{mM}$ Tris- $\mathrm{HCl}, 50 \mathrm{mM}$ $\mathrm{KCI}, 1.5 \mathrm{mM} \mathrm{MgC1} 1_{2}, 100 \mu \mathrm{M}$ of each dNTP, 0.25 $\mu \mathrm{g}$ BSA-bovine serum albumin and 1.5 units of Taq polymerase. The amplification conditions were as follows: one cycle of three minutes at $94^{\circ} \mathrm{C} 45$ cycles consisting of one minute at $94^{\circ} \mathrm{C}$ one minute at $35^{\circ} \mathrm{C}$ two minutes at $72^{\circ} \mathrm{C}$ followed by one cycle of 10 minutes at $72^{\circ} \mathrm{C}$ The amplification products were separated using $1.5 \%$ agarose gel, stained with ethidium bromide and photographed under UV light (UVI-KS 4000i Gel Documentation and Analysis System, UVItec, Ltd, Cambridge, UK).

Taq polymerase, PCR buffer, dNTPs, BSA, and $\mathrm{MgCl}_{2}$ were supplied by MBI Fermentas (Vilnius, Lithuania); 10-mer primers were synthesized by Ramson Hill Bioscience, Inc.(Ramona, CA, USA). The sequences of the primers corresponded to those in Operon 10-mer kits A-P (Operon Technologies Inc. Alameda, CA, USA). All RAPD analyses were standardized, and performed at least twice.

\section{RESULTS}

\section{Cucumber haploid development}

Fruit developed from about $50 \%$ of pollinated flowers and numerous haploid embryos and plants were obtained in four hybrid varieties as a result of pollination with irradiated pollen (Table 1).

Typically, 2 -3 fruit per plant for total of 119 fruit were obtained from pollination of 40 plants in each cultivar. The number of embryos that developed from seeds within five weeks after the pollination ranged between 70 and 116 per

TABLE 1. Cucumber haploid embryo and plant development from four $\mathrm{F}_{1}$ donor cultivars in two environments.

\begin{tabular}{|c|c|c|c|c|}
\hline \multicolumn{5}{|l|}{ a. Spring } \\
\hline $\mathrm{F}_{1}$ donor cultivar & $\begin{array}{c}\text { Fruits } \\
\text { (No.) }\end{array}$ & $\begin{array}{l}\text { Embryos } \\
\text { (No.) }\end{array}$ & $\begin{array}{c}\text { Plants } \\
\text { (No.) }\end{array}$ & $\begin{array}{c}\text { Embroys regenerated } \\
\text { into plants }(\%)\end{array}$ \\
\hline Polan & 132 & 116 & 9 & 7.8 \\
\hline Krak & 102 & 76 & 16 & 21.1 \\
\hline Frykas & 127 & 79 & 15 & 19.0 \\
\hline Izyd & 120 & 85 & 14 & 16.5 \\
\hline Total & 481 & 356 & 54 & 15.2 \\
\hline \multicolumn{5}{|c|}{ b. Summer/Autumn } \\
\hline Polan & 123 & 92 & 20 & 21.7 \\
\hline Krak & 100 & 74 & 31 & 41.9 \\
\hline Frykas & 130 & 70 & 25 & 35.7 \\
\hline Izyd & 117 & 97 & 9 & 9.3 \\
\hline Total & 470 & 333 & 85 & 25.5 \\
\hline
\end{tabular}


cultivar. In total, the number of embryos developed from the four cultivars was similar in each season (356 in spring and 333 in summer/autumn). Average number of embryos that developed into plants varied from experiment to experiment and from cultivar to cultivar, ranging between 7.8 to $41.9 \%$. Haploid plants were obtained in each genetic background, the results were consistent over the two years. Using cytometric evaluation all plants were classified as monohaploids $(n=7)$. These plants were maintained in vitro and vegetatively propagated to provide material for chromosome doubling.

\section{RAPD analysis}

In the first stage of analysis, 240 primers were evaluated using five genotypes (two $2 \mathrm{n}$ regenerants of 'Polan', one $1 \mathrm{n}$ and one $2 \mathrm{n}$ regenerants of 'Izyd', and one $1 \mathrm{n}$ regenerant of 'Frykas'). The tested primers produced on average 10.3 distinctive banding profiles. Those with clear and reproducible amplification profiles were selected for further analysis.

\section{Comparison of haploids and their DH lines}

Selected primers generated 6 to 15 bands, 100 to $2750 \mathrm{bp}$ in size. Eleven haploid plants derived from cvs. 'Izyd',
'Frykas' and 'Krak', gave amplification band patterns identical to their DH plants. The haploid and DH plants derived from the hybrid 'Polan' gave different results. Thirty two out of 40 primers gave identical results, whereas eight primers showed one additional band in DH plants.

\section{Search for RAPD bands associated} with tolerance to Pseudoperonospora cubensis

RAPD analysis was performed to identify primers (selected before using bulked segregant analysis BSA - data unpublished) differentiating between susceptible and resistant plants among haploid and $\mathrm{DH}$ plants developed from hybrids 'Polan' (susceptible), 'Frykas' and 'Izyd' (both resistant). The primers used generated 5 to 19 amplification products. Nine primers generated polymorphic bands that differentiated haploid and DH plants from susceptible 'Polan' and plants derived from the resistant varieties. Among these, five primers (A14, C11, D18, E2, and E14) produced a band present in both, $\mathrm{H}$ and $\mathrm{DH}$ susceptible plants derived from 'Polan'; three primers (B6, E15 and E20) generated an unique band for $\mathrm{H}$ and $\mathrm{DH}$ plants derived from 'Frykas' and 'Izyd'; one primer (D13) generated one band specific for resistant plants and one band specific for suscepti-
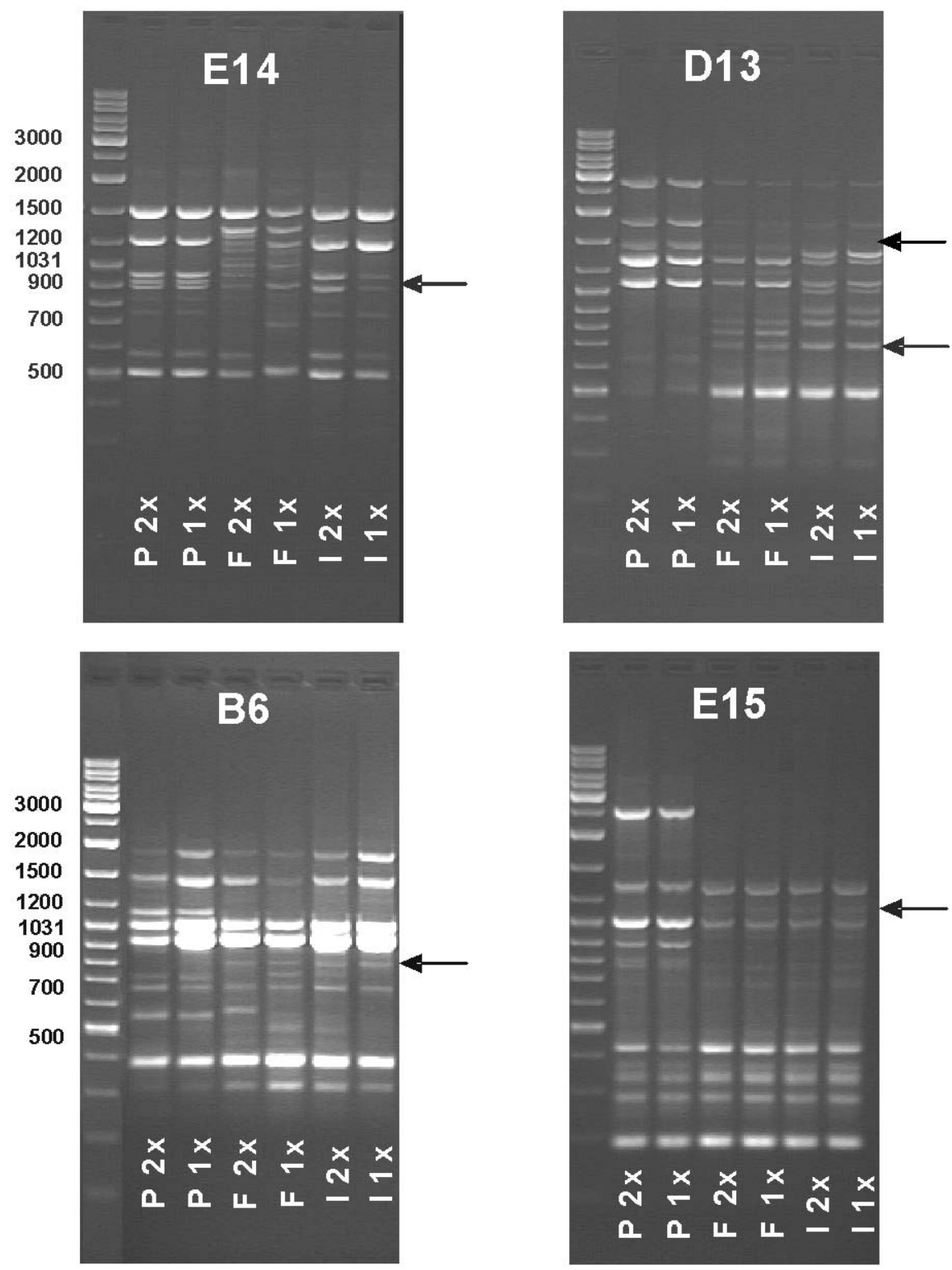

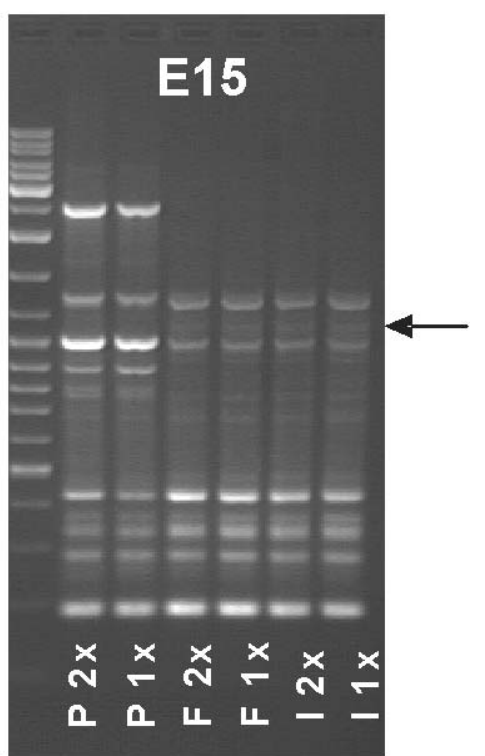

Fig. 1. DNA polymorphism in $\mathrm{H}(1 \mathrm{n})$ and DH (2n) plants derived from susceptible cv. 'Polan' (P) and resistant cvs. 'Frykas' (F) and 'Izyd' (I) generated with the use of primers E14, D13, B6 and E15. Line 1 - MWDNA size marker (GeneRuler ${ }^{\mathrm{TM}}$ DNA Ladder Mix, MBI, Fermentas). 


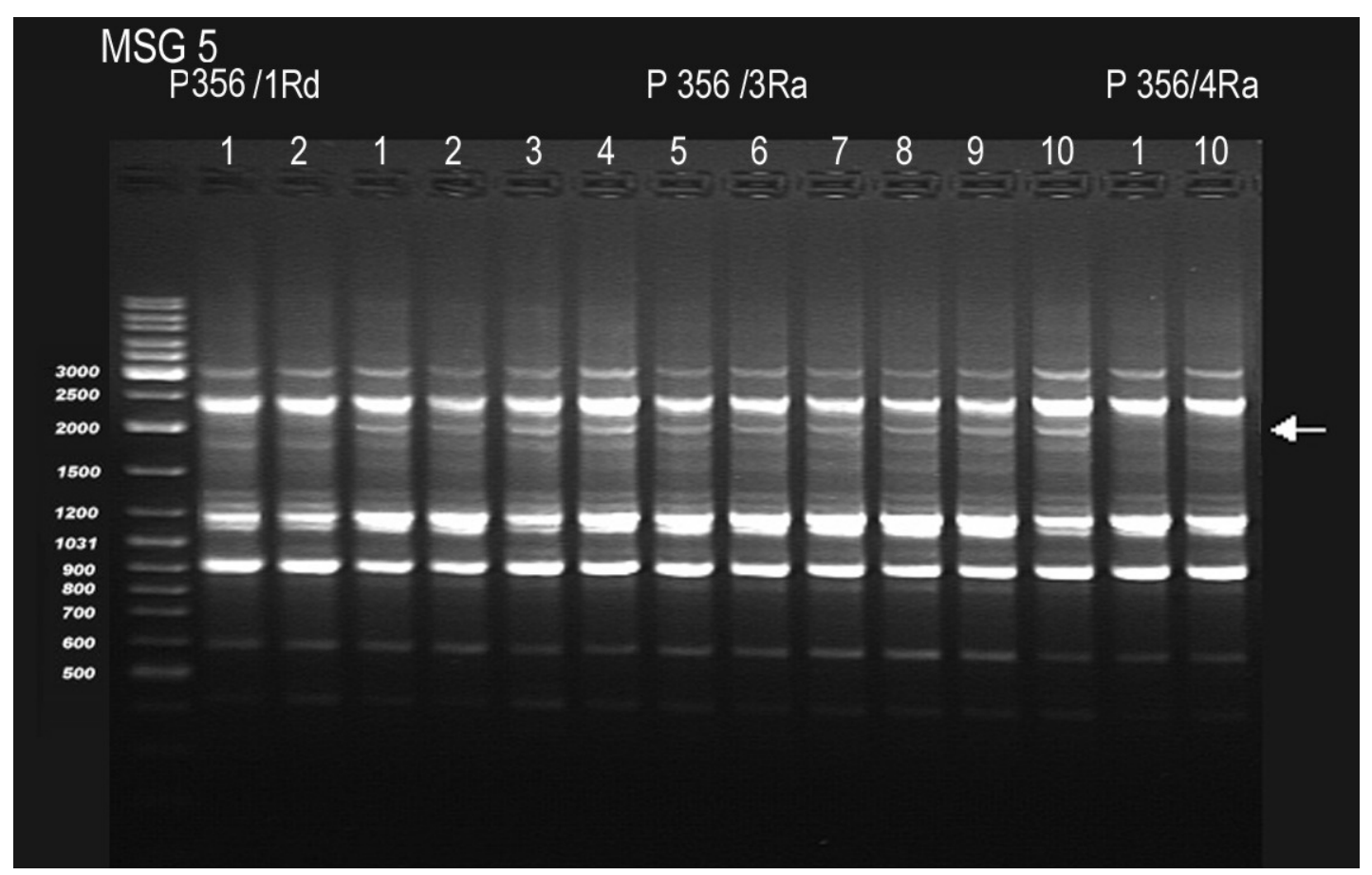

Fig. 2. Amplification profiles (primer G5) of three DH progenies derived from P356 haploid plant. Line 1 - MW-DNA size marker (GeneRuler ${ }^{\mathrm{TM}}$ DNA Ladder Mix, MBI, Fermentas). Lines 2 and 3 - amplification profile of DH plants of P356/1Rd without additional bands. Lines 4-13 - amplification profile of DH plants of P356/3Ra with additional band suggesting somaclonal changes. Lines 14 and 15 - amplification profile of DH plants of P356/4Ra without additional bands.

ble plants. These bands were $580 \mathrm{bp}$ and $1480 \mathrm{bp}$ in size for the resistant and the susceptible plants, respectively. Polymorphism generated by selected primers is shown in Figure 1.

\section{Analysis of somaclonal variation}

Thirteen primers were used to differentiate 21 secondary regenerants $\left(R_{1}\right)$ derived from 11 primary $\left(R_{0}\right)$ regenerants. Five of the 13 primers were discriminatory between $\mathrm{R}_{0}$ and $\mathrm{R}_{1}$ plants and produced one additional band between 1650-3000 bp in size. Among the 11 tested populations, additional bands were detected in three $R_{1}$ populations derived from cultivars 'Polan'(two) and 'Frykas'(one) (Fig. 2).

\section{DISCUSSION}

The frequency of embryo development was comparable in the two experiments performed in this study (about 0.7 embryo per fruit).This efficiency is not considered high when compared to the efficiency of 1.2 to 3.1 embryos per fruit published earlier (Przyborowski and NiemirowiczSzczytt 1994). However, the results presented here are unique in the fact that embryos and haploid plants were obtained from each of the four tested varieties.

Reported here frequency of plant regeneration, calculated by dividing the total number of plants by the number of ovaries that produced embryos, ranges from 0.07 to $0.31 \%$. Frequency of 0.0 to $7.1 \%$, was reported by Gemes-Juhasz et al. (2002), however, in that study the plantlets were obtained through ovary culture.

Presented here results are similar to those observed in muskmelon (Cucumis melo L.) which has been studied to a greater extent than cucumber (Sauton and Dumas de Vaulx 1987; Cuny et al. 1993; Ficcadenti et al. 1995; Abak et al. 1996; Ficcadenti et al.1999; Lotfi et al. 2003).
It was reported that ovary culture results in fewer plants and in the increase in the percentage of mixoploids as compared to haploid embryo rescue (Ficcadenti et al.1999; Lotfi et al. 2003). In contrast, pollination with irradiated pollen, embryo rescue, and subsequent in vitro culture, was reported to produce stable muskmelon haploid plants (Sauton and Dumas de Vaulx 1987; Cuny et al. 1993; Ficcadenti et al. 1995; Abak et al. 1996). The latter method clearly produces more desirable results.

The application of RAPD analysis using selected 28 primers has shown that it was possible to obtain identical amplification profiles for 11 haploids and obtained from them DH plants derived from cultivars 'Izyd', Frykas', and 'Krak'. Each of the 11 haploid plants had a distinctive banding profile that was identical to the profile obtained for derived from them diploids. This result suggests that it should be possible to use RAPD analysis for selection of distinctive genotypes at the haploid level. Selection at the haploid level would allow early elimination individuals not containing desirable characteristics, such as disease resistance.

Unfortunately, this strategy is not applicable to all populations of haploids and their DH lines, for instance additional banding pattern was observed in the $\mathrm{DH}$ plants derived from cultivar 'Polan' as compared to the haploid plants. Therefore, the concept of early selection at the haploid level using RAPD analysis requires further study and optimisation.

Another outcome of this study was identification of primers that generated highly specific amplification profiles allowing differentiation among $\mathrm{H}$ and $\mathrm{DH}$ lines derived from different varieties. Identification of cultivar-specific polymorphism is particularly useful in cucumber, which is characterized by a relatively low level of polymorphism in general (Kennard et al. 1994). 
The marker study performed to differentiate resistance and susceptibility to downy mildew was preliminary, and was limited to the assessment of primers identified in the pilot study. Further research is needed to verify linkage between the identified markers and the susceptible and resistant phenotypes in progenies obtained from crosses between DH lines derived from the susceptible cultivar 'Polan' and resistant to downy mildew DH lines identified in this study. The marker-phenotype linkage needs to be verified before these markers are used in practical selection.

Horejsi et al. (2000) reported five RAPD markers linked to downy mildew resistance gene $(d m)$, among which one of the primers, G14, was linked to $d m$ at $16.5 \mathrm{cM}$. The same primer was used in this study, but it did not differentiate between resistant and susceptible plants. Furthermore, primers that we report as generating polymorphic products allowing differentiation between resistant and susceptible plants were described as not effective in the cited above publication. It is possible that a conversion of RAPD products into sequence specific transferable SCAR markers could result in more unambiguous evaluation (Myburg et al. 1998; Liu et al. 1999; Janila and Sharma 2004).

An important goal of the RAPD analysis was to confirm the genetic homogeneity of the DH lines. Only three DH lines out of 21 lines derived from three cultivars and tested with five selected primers showed an additional band 1650-3000 bp in size. The presence of an additional band may be indicative of somaclonal variation. Moreover, the banding pattern shows the somaclonal changes to be homozygotic, a phenomenon that is characteristic of tissue culture as a source of genetic variation (Karp 1995).

The applicability of the RAPD methodology for the documentation of somaclonal variation is a subject of discussion (Anastassopoulos and Kleil 1996; Fourre et al. 1997; Saker et al. 2000; Phong et al. 2001; Tang 2001). The results of the tests are highly dependent on the number of the primers used and the number of plant lines. As reported here, the results of the RAPD analysis are in agreement with the phenotypic uniformity of the DH lines. This is not, however, a guarantee that the results would be similar if more different primers were tested.

\section{ACKNOWLEDGEMENTS}

This research was partially supported by grant from AWRSP - Poland. The authors thank E. Gniazdowska and J. Szewczyk for careful technical assistance.

\section{LITERATURE CITED}

ABAK K., SARI N., PAKSOY M., YIMAZ H., AKTAS H., TUNALI C. 1996. Genotype response to haploid embryo induction with pollination by irradiated pollen in melon, production of dihaploid lines, and determination of haploid and diploid plants by different techniques. Turk J. Agric. For. 20: 425-430.

ANASTASSOPOULOS E., KLEIL M. 1996. Assessment of natural and induced genetic variation in Alstremeria using amplified polymorphic DNA (RAPD) markers. Euphytica 90: 235-244 .

BEEK van der J.G., VERKERK R., ZABEL P., LINDHOUT P. 1992. Mapping strategy for resistance genes in tomato based on RFLPs between cultivars: Cf9 (resistance to Cladosporium fulvum) on chromosome 1. Theor. Appl. Genet. 84: 106-112.
CAGLAR G., ABAK K. 1996. The effect of season and irradiation doses on haploid embryo production in cucumber ( $\mathrm{CuCu}$ mis sativus L.). Proc. VIth Eucarpia Meeting on Cucurbit Genetics and Breeding, Malaga, 28-30 May, 1996, 25-30.

CUNY F., GROTTE M., DUMAS de VAULX R., RIEU A. 1993. Effect of gamma irradiation of pollen on parthenogenetic haploid production in muskmelon (Cucumis melo L.). Environ. Exp. Bot. 33: 301-312.

DORUCHOWSKI R., ŁĄKOWSKA-RYK E. 1992. Inheritance of resistance to downy mildew (Pseudoperonospora cubensis Berk \& Court) in Cucumis sativus. Proc. 5th Eucarpia Cucurbitaceae Symp. Warsaw, Poland: 66-69.

FARIS N.M., RAKOCZY-TROJANOWSKA M., MALEPSZY S., NIEMIROWICZ-SZCZYTT K. 2000: Diploidization of cucumber (Cucumis sativus L.) haploids by in vitro culture of leaf explant. In: Food Biotechnology, S. Bielecki, J. Tramper, J. Polak (eds). Elsevier Science: 49-54.

FICCADENTI N., VERONESE P., SESTILI S., CRINO P., LUCRETTI S., SCHIAVI M., SACCARDO F. 1995. Influence of genotype on the induction of haploids in Cucumis melo L. by using irradiated pollen. J Genet. Breed. 49: 359-364.

FICCADENTI N., SESTILI S., ANNIBALI S., MARCO M., SCHIAVI M. 1999: In vitro gynogenesis to induce haploid plants in melon Cucumis melo L. J. Genet. Breed. 53. 255$-257$.

FOURRE J.L., BERGER P., NIQUET L., ANDRE P. 1997. Somatic embryogenesis and somaclonal variation in Norway spruce: morphogenetic, cytogenetic and molecular approaches. Theor. Appl. Genet. 94: 159-169.

GEMES-JUHASZ A., BALOGH P., FERENCZY A., KRISTOF Z. 2002. Effect of optimum stage of female gametophyte and heat treatment on in vitro gynogenesis induction in cucumber (Cucumis sativus L.). Plant Cell Rep. 21: 105-111.

HOREJSI T., STAU J.E., THOMAS C. 2000. Linkage of random amplified polymorphic DNA markers to downy mildew resistance in cucumber (Cucumis sativus L.). Euphytica 115: 105-113.

JANILA P., SHARMA B. 2004. RAPD and SCAR markers for powdery mildew resistance gene $\mathrm{er}$ in pea. Plant Breeding 123: 271-274.

KARP A. 1995. Somaclonal variation as a tool for crop improvement. Euphytica 85: 295-302.

KENNARD W.C., POETTER K., DIJKHUIZEN A., MEGALIC V., STAUB J.E., HAVEY M. 1994. Linkage among RFLP, RAPD, izozyme, disease resistance and morphological markers in narrow and wide crosses of cucumber. Theor. Appl. Genet. 89: 42-48.

LIU Z., SUN Q., NI Z., YANG T. 1999. Development of SCAR markers linked to the $P m 21$ gene conferring resistance to powdery mildew in common wheat. Plant Breed. 118: 215-219.

LOTFI M., ALAN A.R., HENNIN M.J., JAHN M.M., EARLE E.D 2003. Production of haploid and doubled haploid plants of melon (Cucumis melo L.) for use in breeding for multiple virus resistance. Plant Cell. Rep. 21: 1121-1128.

MURASHIGE T., SKOOG F. 1962. A revised medium for rapid growth and bioassays with tobacco tissue cultures. Physiol. Plant. 15: 473-497.

MYBURG A.A., CAWOOD M., WINGFIELD B.D., BOTHA A.M. 1998. Development of RAPD and SCAR markers linked to the Russian wheat aphid resistance gene in Dn2 in wheat. Theor. Appl. Genet. 96: 1162-1169.

NIEMIROWICZ-SZCZYTT K., DUMAS de VAULX R. 1989. Preliminary data on haploid cucumber (Cucumis sativus L.) induction. Cucurbit Genet Coop Rpt 12: 24-25.

NIKOLOVA V., NIEMIROWICZ-SZCZYTT K. 1996. Diploidization of cucumber (Cucumis sativus L.) haploids by colchicine treatment. Acta Soc. Bot. Pol. 65: 311-317.

PHONG D.T., MUOI L.T., BINH L.T. 2001. RAPD variability in rice (Oryza sativa L.) plants derived from desiccation-tolerant calli. Euphytica 121: 297-303. 
PRZYBOROWSKI J., NIEMIROWICZ-SZCZYTT K. 1994. Main factors affecting cucumber (Cucumis sativus L.) haploid embryo development and characteristics. Plant Breed. 112: 70-75.

SAKER M.M., BEKHEET S.A., TAHA H.S., FAHMY A.S., MOURSY H.A. 2000. Detection of somaclonal variations in tissue culture-derived data palm plants using isoenzyme analysis and RAPD fingerprints. Biol Plant. 43: 347-351.

SAUTON A., DUMAS de VAULX R. 1987. Obtention de plantes haploides chez le melon (Cucumis melo L.) par gynogenese induite par du pollen irradie. Agronomie 7: 141-148.
SAUTON A. 1989: Haploid gynogenesis in Cucumis sativus L. induced by irradiated pollen. Cucurbit Genet. Coop. Rpt. 12: 22-23.

TANG W. 2001. In vitro regeneration of loblolly pine and random amplified polymorphic DNA analyses of regenerated plantlets. Plant Cell Rep. 20: 163-168.

TRUONG-ANDRE I. 1988: In vitro haploid plants derived from pollination by irradiated pollen of cucumber. Proc. Eucarpia Meet. Cucurbit. Avignon-Montfavet, France, 143-144. 